\title{
Design of Biofilter Odor Removal System for Conventional Wastewater Treatment Plant
}

\author{
Ali Hadi Ghawi ${ }^{1}$ \\ 1 Department of Civil Engineering, Collage of Engineering, University of Al-Qadisiyah, Iraq \\ * Corresponding author's e-mail: ali.ghawi@qu.edu.iq
}

\begin{abstract}
Control of odor removal and air pollution in wastewater treatment plants has become critical because of the negative impacts of invasive pollutants that are no longer limited to the working environment of sewage treatment plants, but extend to nearby residential areas when appropriate weather conditions are present. Residents of the city of Al-Nasiriyah in Iraq suffer from the the foul odors from the Jazeera Wastewater Treatment Plant in the city of Al-Nasiriyah, located in the province of Dhi Qar in southern Iraq. Therefore, efforts must be intensified to reduce the risks they pose to the ecosystem and the serious damage to human health. In this study, a biofilter system was designed to remove the odors emitted (hydrogen sulfide and ammonia gas) from the conventional activated sludge Al-Nasiriyah- Jazeera wastewater treatment plant. The biofilter odor removal system is designed for inlet screw pumping station, screening station, aerated grit chamber and parshall flume inlet. The result of the design of the biofilters, which meets the environmental requirements of Iraq according to the law of environmental protection No. 27 of 2009 and its instructions No. 3 of 2011 was the inlet screw pumping station (volume of buildings to be treated $-400 \mathrm{~m}^{3}$, number of changes per hour $>5 \mathrm{n} / \mathrm{h}$, design flow rate to be captured and treated $-2000 \mathrm{~m}^{3} / \mathrm{h}, \mathrm{H}_{2} \mathrm{~S}$ removal efficiency $>98 \%$, volume of substrate media $-24 \mathrm{~m}^{3}$, height of surface media $-1.4 \mathrm{~m}$, and overall dimension (length $-8.9 \mathrm{~m}$, height $-2.27 \mathrm{~m}$, width $-2.13 \mathrm{~m}$ )), as well as the preliminary treatments screening station, aerated grit chamber and parshall flume inlet (volume of buildings to be treated (each biofilter) $-400 \mathrm{~m}^{3}$, number of changes per hour $-12 \mathrm{n} / \mathrm{h}$, design flow rate to be captured and treated (each biofilter) $-5000 \mathrm{~m}^{3} / \mathrm{h}, \mathrm{H}_{2} \mathrm{~S}$ removal efficiency $>98 \%$, volume of substrate media $-60 \mathrm{~m}^{3}$, height of surface media $-1.4 \mathrm{~m}$, and overall dimension (length $10.6 \mathrm{~m}$, height $2.27 \mathrm{~m}$, width $\mathrm{m} 2.13 \mathrm{~m}$ )).
\end{abstract}

Keywords: Biofilter, Wastewater, Hydrogen Sulfide, Odor

\section{INTRODUCTION}

The biological treatment of municipal wastewater is typically based on the so-called activated sludge process, i.e. on the use of suspended biomass capable to oxidize organic compound (Pedro Cisterna, 2017). Experts on wastewater treatment have found the need to address odor as a primary concern in the design and operation of collection and treatment facilities. Any place or process in which wastewater is collected, transported or treated has the potential to generate and release nuisance odors to the surrounding area. However, most odor problems occur in the collection system, in primary treatment facilities and in solids handling facilities. In most instances, the odors associated with collection systems and primary treatment facilities are generated as a result of an anaerobic or "septic" condition. This condition occurs when the oxygen transfer to the wastewater is limited, such as in a force main. In the anaerobic state, the microbes present in the wastewater have no dissolved oxygen available for respiration. This allows the microbes known as "sulfate-reducing bacteria" to thrive. These bacteria utilize the sulfate ion $\left(\mathrm{SO}_{4}^{-}\right)$that is naturally abundant in most waters as an oxygen source for respiration. The byproduct of this activity is hydrogen sulfide $\left(\mathrm{H}_{2} \mathrm{~S}\right)$. This byproduct has low solubility in the wastewater and a strong, offensive, rotten-egg odor. In addition to its odor, $\mathrm{H}_{2} \mathrm{~S}$ can cause severe corrosion problems as well. 
Due to its low solubility in the wastewater, it is released to the atmosphere in such areas as wet wells, head works, grit chambers and primary clarifiers. There are typically other "organic" odorous compounds, such as mercaptans and amines, present in these areas, but $\mathrm{H}_{2} \mathrm{~S}$ is the most prevalent compound (Ben Jaber et al., 2016).

Solids handling facilities are another significant problem area connected with odor. In biosolids dewatering and treatment processes, the biosolids commonly undergo extreme turbulence, $\mathrm{pH}$ adjustment and/or thermal treatment. Depending on the nature of the biosolids stream and the treatment used, the odor compounds released can consist of any combination of the following compounds in a wide range of concentrations: ammonia $\left(\mathrm{NH}_{3}\right)$, amines, hydrogen sulfide, organic sulfides and mercaptans. Additionally, the anaerobic digestion of sludge creates the anaerobic conditions under which sulfate-reducing bacteria thrive, causing the formation of hydrogen sulfide that is vented with the digester "biogas" formed from the digestion of sludge. There are many different technologies that can be applied to control the odors from wastewater collection and treatment systems. These technologies can be split into two main groups: vapor-phase technologies, used to control odorous compounds in the air or gas; and liquid-phase technologies, used to control odorous compounds in the liquid wastewater itself. The vapor-phase technologies are typically used in point-source applications such as wastewater treatment plants and pump stations or for the treatment of biogas. On the other hand, the liquid-phase technologies are typically used in the collection systems where control of both odors and corrosion are concerns and/or where multiple point odor control is objective (Fletcher et al., 2014).

The objective of this study is to design the Odor Control System for the Jazeera wastewater treatment plant in Nasiriyah, Dhi Qar Governorate, in southern Iraq, according to the environmental requirements under the Environment Protection Law No. 27 of 2009 and the Instructions No. 3 of 2011. The Dhi Qar sewerage department took the necessary measures to protect the population and the environment from the negative effects of sewage projects. The most important negative effects of wastewater treatment plants include the emission of gases such as hydrogen and ammonium gases that constitute aromatic and undesirable odors in the environment and health.
In this study, the SERECO S.r.l. technology was used in the design of the odor removal system.

The removal of these odors is based on the elimination of emitted gases using specialized technological systems that absorb these gases and prevent them from spreading in the surrounding environment of the wastewater treatment plants, especially taking into account the fact that the sites of these plants are sometimes within the residential neighborhoods imposed by the design determinants of sewage networks. Where the smells emitted from the sewage treatment plant are concentrated in the inlet of a screw pumping station, screening station, aerated grit chamber and parshall flume inlet, the preferred technical and environmental solution is to cover these systems technically using a GRP cover with the air withdrawn through effective biological filters (Estrada et al., 2011). The aim of this study is to describe the selection and design of the air treatment units for odor removal from selected areas of the AlNasiriyah wastewater treatment plant (NWWTP).

\section{MATERIAL AND METHODS}

\section{Description Al-Nasiriyah Wastewater Treatment Plant (NWWTP)}

The sewage treatment plant in the city of AlNasiriyah in the province of Dhi Qar is one of the strategic projects of the giant infrastructure, serving 300,000 people. The district of Nasiriyah is located about $375 \mathrm{~km}$ to the southeast of the city of Baghdad. It processes wastewater to minimize its negative impact and dumps it into the Euphrates River. The area of wastewater treatment unit is $(140 \times 428) \mathrm{m}$. The location of the plant is within the limits of the city's basic design and is close to densely populated areas. The Wastewater Treatment Plants (WWTPs) have the capacity of $60000 \mathrm{~m}^{3} /$ day. They are of conventional activated sludge process type, as shown in Figures 1 and 2. In this solution, the raw wastewater passes three stages of treatment; primary treatment where suspended solids settled or retained, secondary treatment where the biological process is taking place to transform dissolved and suspended organics into simple compounds, then the third stage where sludge stabilization takes place in digestion systems. The Iraqi National Standards set by the Regulation 25 of 1967 for the design and specifications of wastewater raw and treated sew- 


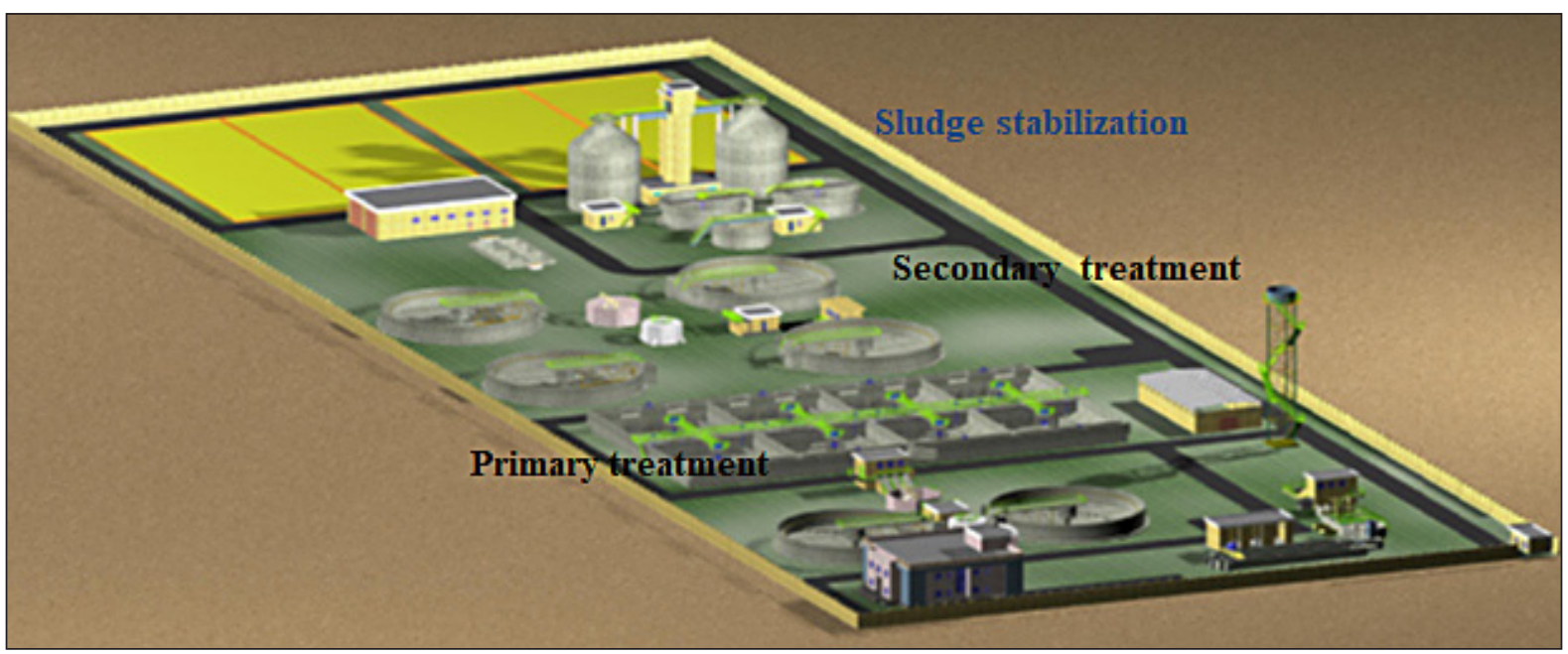

Figure 1. General layout of Al-Nasiriyah WWTP (Water line: Screening- Aerated grit chamber and Parshall flume inlet - Primary settling - Biological Treatment - Secondary Settling -Disinfection. Sludge line: Thickening - Blending - Anaerobic digestion - Drying beds)

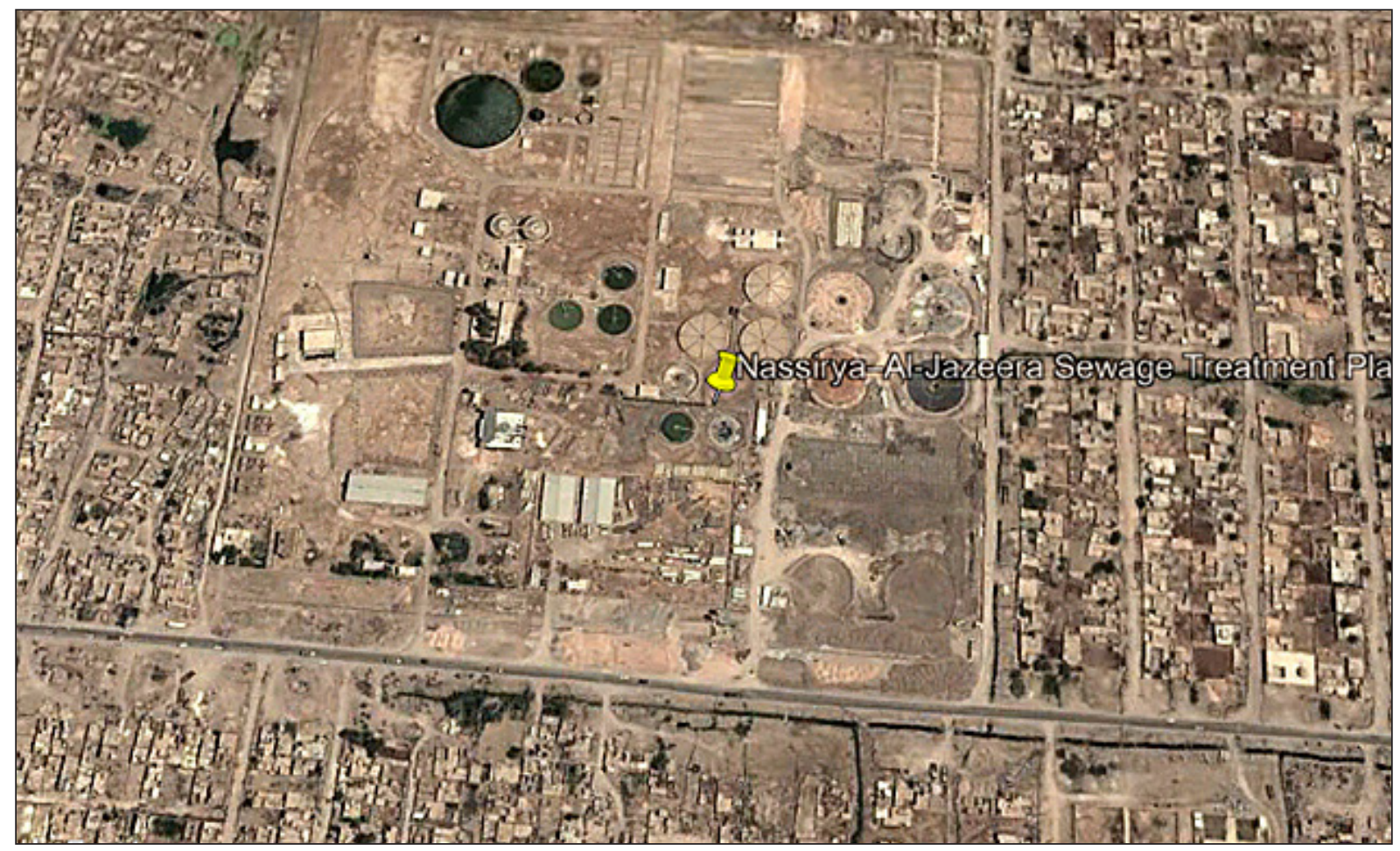

Figure 2. The Study Area

age from a domestic wastewater treatment unit also the capacity and technological parameters of this study are as follows (Table 1):

\section{PROCESS SELECTION}

In general, the odor control facilities at the WWTP consist of selected plant sections, aspiration of exhausted air and treatment for odor- ants degradation or removal. Typically, the designed air flow rate must guarantee 4-6 volume exchanges per hour in covered sections were the access for operators is restricted and 10-12 volume exchanges where the presence of operators is required for routine operations (WEF., 2004). Continuous air aspiration must guarantee the required ventilation rates and maintain a negative differential pressure across openings in the covered area. Other odor control strategies are 
Table 1. Influent and effluent criteria of Al-Nasiriyah WWTP

\begin{tabular}{|c|c|}
\hline Parameter & Values \\
\hline Equivalent inhabitants & 316083 inha. \\
\hline $\begin{array}{r}\text { Design Flow rate: } \\
\text { Average } \\
\text { Max } \\
\text { Min }\end{array}$ & $\begin{array}{l}2897 \mathrm{~m}^{3} / \mathrm{h} \\
4708 \mathrm{~m}^{3} / \mathrm{h} \\
1738 \mathrm{~m}^{3} / \mathrm{h}\end{array}$ \\
\hline \multicolumn{2}{|c|}{ Characteristic of influent sewage: } \\
\hline TSS & $400 \mathrm{mg} / \mathrm{L}$ \\
\hline COD & $460 \mathrm{mg} / \mathrm{L}$ \\
\hline BOD5 & $350 \mathrm{mg} / \mathrm{L}$ \\
\hline TKN & $40 \mathrm{mg} / \mathrm{L}$ \\
\hline $\mathrm{NH} 3-\mathrm{N}$ & $20 \mathrm{mg} / \mathrm{L}$ \\
\hline NO3-N & $<1 \mathrm{mg} / \mathrm{L}$ \\
\hline TP & $8 \mathrm{mg} / \mathrm{L}$ \\
\hline $\mathrm{pH}$ & 7 \\
\hline BOD5 loading & $24340 \mathrm{~kg} / \mathrm{d}$ \\
\hline \multicolumn{2}{|l|}{ Treated effluent limits: } \\
\hline TSS & $30 \mathrm{mg} / \mathrm{L}$ \\
\hline COD & $100 \mathrm{mg} / \mathrm{L}$ \\
\hline BOD5 & $20 \mathrm{mg} / \mathrm{L}$ \\
\hline TKN & $7 \mathrm{mg} / \mathrm{L}$ \\
\hline TP & $2 \mathrm{mg} / \mathrm{L}$ \\
\hline $\mathrm{pH}$ & 7 \\
\hline $\begin{array}{c}\text { Wastewater Temperature: } \\
\text { Design } \\
\text { Min } \\
\text { Max }\end{array}$ & $\begin{array}{l}20^{\circ} \mathrm{C} \\
15^{\circ} \mathrm{C} \\
35^{\circ}\end{array}$ \\
\hline
\end{tabular}

related to the addition of oxidizing chemicals to the influent wastewater or spraying on scum, screened materials, etc. Moreover, masking or neutralization of volatile odor compound can be performed by spraying suitable liquid mixtures of fragrances and surfactants. However, the efficiency of these techniques is somewhat uncertain and difficult to control.

A range of technologies is available to treat the odorous air aspired from confined sections at wastewater treatment plants and sludge handling facilities. These can be classified according to the main process involved in the odor removal:

- Biochemical: biofilters, bioscrubbers, activated sludge;

- Chemical: scrubbers, thermal oxidation, catalytic oxidation, ozonation;

- Physical: condensation, adsorption (activated carbon), absorption (clean water scrubbers).

The selection of a particular technology or combination of technologies is dependent on factors such as: site characteristics including operation and maintenance capabilities, treatment objectives, foul air flow rates, contaminant loading patterns, as well as the characteristics and strength of odorous air.

Waste gases from industry have traditionally been treated using the physicochemical processes (scrubbing, adsorption, condensation, and oxidation). However, for municipal wastewater treatment plants, the biological methods of odor treatment are widely applied in Europe and are increasing the USA, owing to their efficiency, cost-effectiveness, and environmental acceptability (Burgess et al., 2001).

The advantage of the biological treatments over physicochemical techniques relies on reduction of the operating costs. For example, yearly biofiltration operating costs are reported to be around one-tenth of those of an absorption process and one-fourth of those of a wet chemical scrubber (Gabriel and Deshusses, 2004). Moreover, adoption of biological treatments eliminates the need of purchasing dangerous chemicals and handling them in concentrated solutions.

Among other biochemical technologies, the biofilters offer simpler operations and maintenance, with very limited use of chemicals and with the main operational cost related to the replacement of the biofilter media (once every 2-5 years). Moreover, biofilters are particularly suited for the odor removal in wastewater treatment plants characterized by constant contaminant loads. For these reasons, the biofiltration technology has been preferred for foul air treatment at the Al-Nasiriyah - Al-Jazeera Wastewater Treatment Plant (NWWTP).

\section{BIOFILTER DESCRIPTION}

A biofilter is simply a bed of organic material (media) with a suitable porosity, allowing for air passage, humidity trapping and biomass growth. As the foul air passes upward through the media, the odor causing compounds are adsorbed onto a film of water and microbes developed on the organic material. These microbes then convert the adsorbed compounds by oxidizing them to carbon dioxide, water and inorganic salts. The biofilter is a self-regulating ecosystem, and is therefore likely to function for long time, without excessive control. It is very important, however, to ensure that the moisture levels are controlled in the biofilter for it to function properly. The $\mathrm{pH}$ levels are also self-regulating within the ecosystem, and are assisted by proper choice of media. The effec- 
tiveness of the biofilter is primarily a function of the amount of time the odorous air spends in the biofilter (contact time) and the moisture content of the filtering material. The biofiltration technology has been developed for over 100 years and its many applications generally differ for the filtering media (soil, compost, wood chips and various mixture) and for the biofilter construction (in-ground or in vessel above the ground, covered or open air).

A typical biofilter has the following basic constructed components: 1) the containment 2) the biofilter media, 3) the humidifier and wetting systems, 4) biofilter air diffusion system and 5) the air ducts and fans (Figure 3).

The technical solution adopted for the Al-Nasiriyah-Al-Jazeera Wastewater Treatment Plant (NWWTP) is a modular self-contained biofilter. This system requires a smaller footprint than the open-bed designs and it is easy to install on a simple concrete basement.

The biofilter is completely pre-assembled in a tank containing the full system, with the dimensions compatible for shipment inside standard containers. The filtering bed substrate is composed of calibrate mixing of high quality wood chips, characterized by high grade of porosity, high retention of humidity. The biofilter coverage ensure the optimal life conditions of the bacteria, avoiding the direct exposition to the sun light that would be responsible for the drying of the bed. Moreover, the biofilter is equipped with an automatic humidification system composed of spray nozzles, solenoid valves, temperature and relative humidity sensor, as well as a control panel. The biofilter is completed by a centrifugal blower for the aspiration of the foul air from the confined sections of the plant and a system of steel piping to connect the blower to the tank. During the start-up, the biofilter can be inoculated with dedicated bacteria or with activated sludge. After the acclimation period, the biofilter reach high efficiency in removing $\mathrm{H} 2 \mathrm{~S}(>98 \%$ at inlet maximum concentration of $100 \mathrm{mg} / \mathrm{l}), \mathrm{NH} 3(95 \%$ at inlet maximum concentration of $30 \mathrm{mg} / \mathrm{l}$ ), and reducing smells. The acidification trend of the bed, due to the air pollutant concentration, is soon eliminated by the action of the biofilter media, then the check of the bed $\mathrm{pH}$ has to be rarely executed, with simple laboratory examinations or with field instrumentations. The temperature and humidity sensor verify the right working of the system, by regulating the opening time of the solenoid valve depending on the humidification of the bed. Under normal operating conditions, the expected duration of the bed is more than 2 years.

\section{RESULTS AND DISCUSSIONS}

\section{Odor generation and treatment and Design Criteria}

Generally, the odorous compounds released from a wastewater treatment plant are not directly related to sanitary problems for plant operators

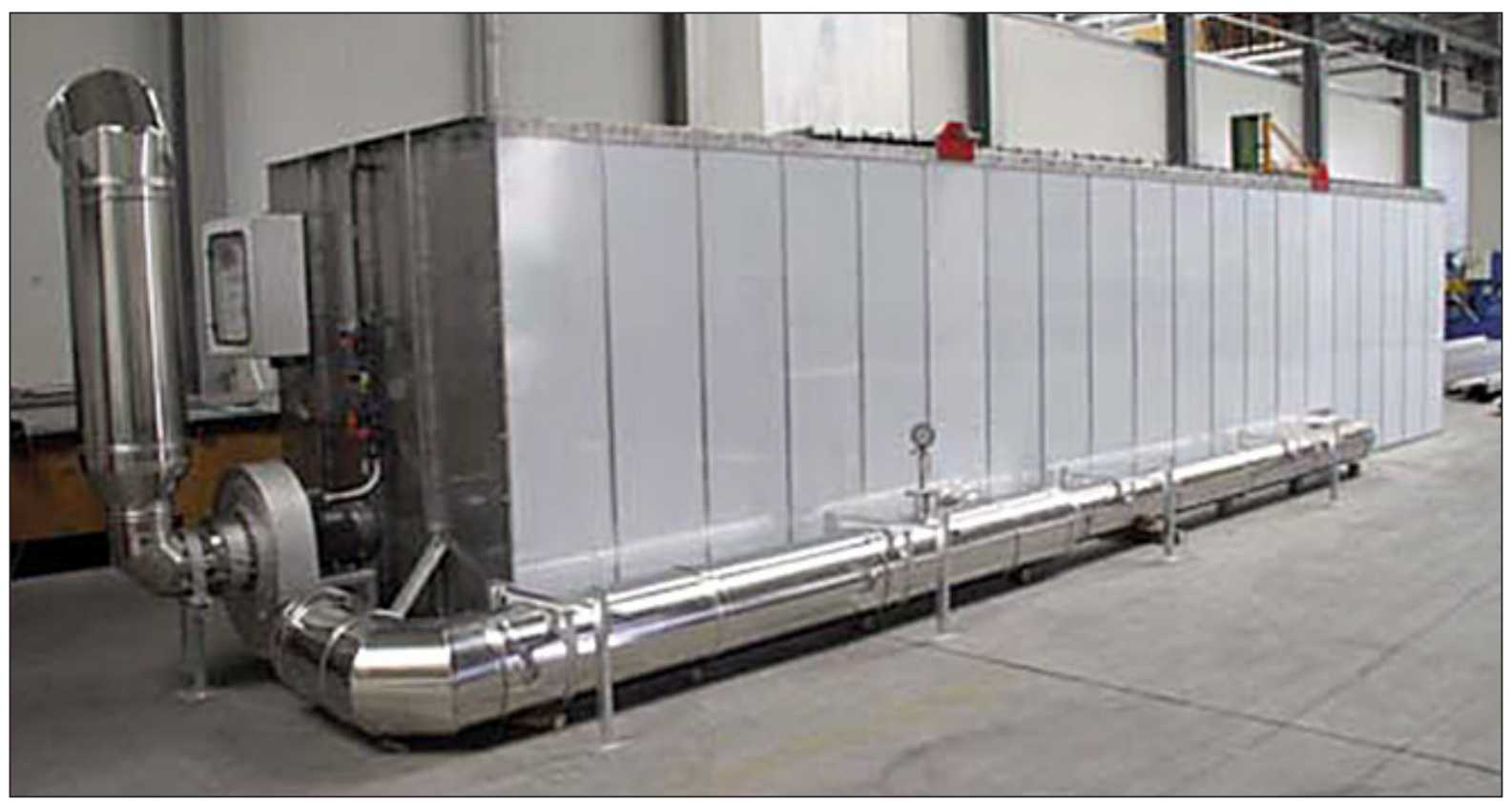

Figure 3. Typical biofilter 
and people living/working in the neighbor area. However, the odor release from wastewater treatment plant can cause significant public concern and control of odor has become a standard consideration in design and operation of wastewater and sludge treatment and disposal facilities. Odorous compounds can be generated during the wastewater collection and transport into the sewer as well as during the various operations in the treatment plant. Within the wastewater treatment plant, the following sections are generally agreed as being the main sources of odors release:

- Preliminary treatments (including pumping station, influent channels and distributors, screens, sand and oil/grit/grease removal units, equalization and pre-aeration systems).

The odors released from preliminary treatments are mainly generated into the sewer and are typically dominated by hydrogen sulfide $\left(\mathrm{H}_{2} \mathrm{~S}\right)$, with other organic sulfur compounds (mercaptans, dimethyl sulfide, etc.) also present at lower concentrations. Odors with similar origin and composition can be released from the large emitting surface of the primary settling tanks. Minor on-site odor generation can be associated with the collection/storage system for screened materials, grease and scum (especially in the summer periods, if this highly putrescible material is not rapidly disposed of). Ammonia and amines can be released from the latter process and especially in the case of alkaline sludge stabilization. The typical $\mathrm{H}_{2} \mathrm{~S}$ concentrations measured in the exhausted air are reported in the Table 2 (WERF 2003):

\section{Process design}

The following stations have been identified as main potential sources of odor at the NWWTP:

- Preliminary treatments (inlet screw pumping station, screening station, aerated grit chamber and inlet parshall flume) (Figure 4).

On the basis of the geometry and the typical ordinary operation for the selected stations, the presence of operators in the confined volume has been excluded. This results in the minimization of

Table 2. Typical $\mathrm{H}_{2} \mathrm{~S}$ concentration measured in the exhausted air

\begin{tabular}{|l|c|c|}
\hline \multicolumn{1}{|c|}{ Section } & $\begin{array}{c}\text { Typical Range } \\
\left(\mathrm{H}_{2} \mathrm{~S} \mathrm{ppm}\right)\end{array}$ & $\begin{array}{c}\text { Typical } \\
\text { Average } \\
\left(\mathrm{H}_{2} \mathrm{~S} \mathrm{ppm}\right)\end{array}$ \\
\hline $\begin{array}{l}\text { Inlet screw pumping } \\
\text { station }\end{array}$ & $5 \div 150$ & 32 \\
\hline Screening station & $3 \div 20$ & 9 \\
\hline $\begin{array}{l}\text { Aerated grit tanks and } \\
\text { parshall flume }\end{array}$ & $0.01 \div 4$ & - \\
\hline
\end{tabular}

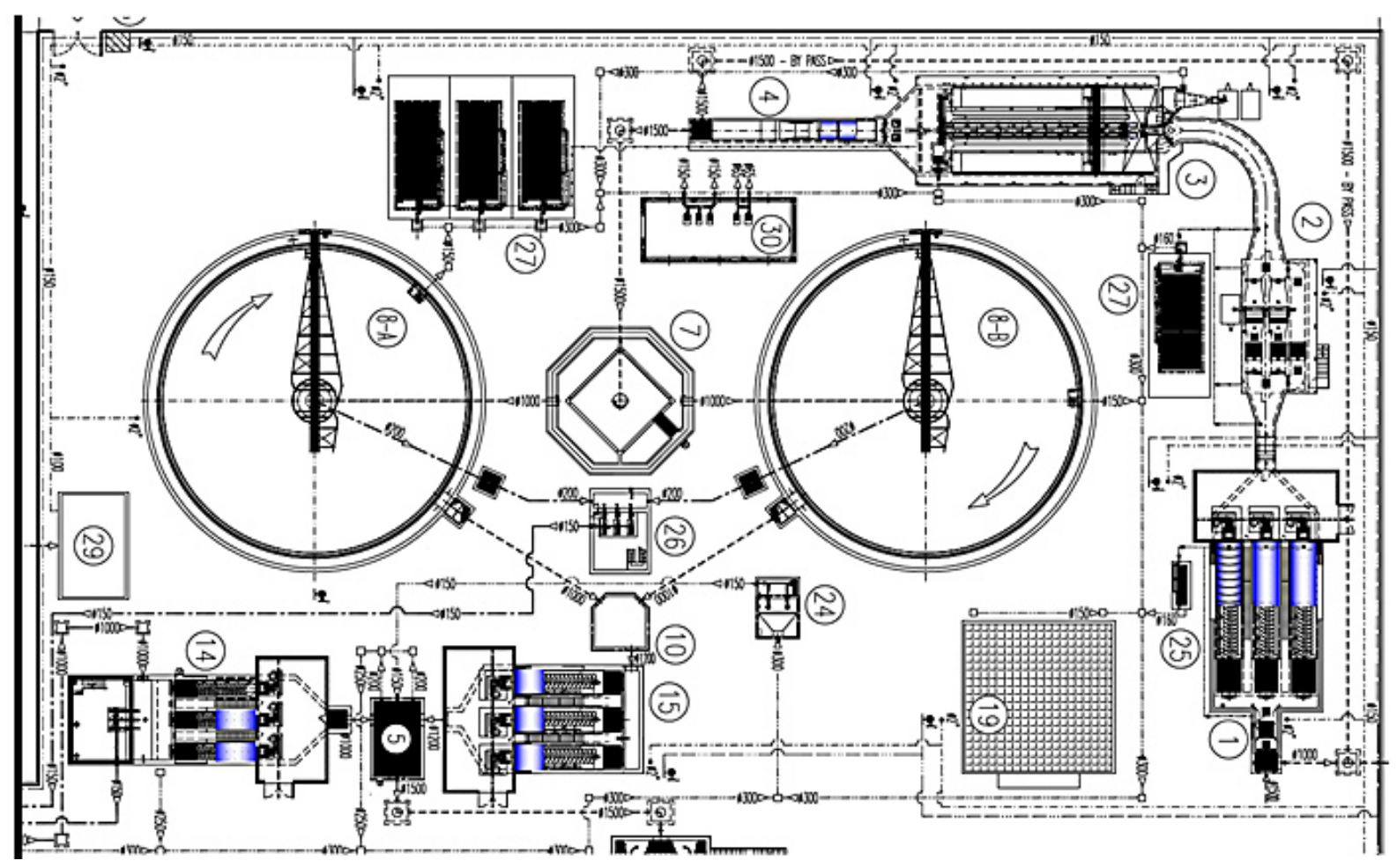

Figure 4. Biofilter for inlet screw pumping station (25), screening station biofilter (27), aerated grit chamber and parshall flume inlet biofilter (27). 
the confined volumes and in the selection of the lower range of ventilation ratios, with consequent reduction of the capital and operational costs of the odor treatment units.

Specific air flow rates for each covered section have been designed assuming minimum 4 volume changes plus any forced air inlet (i.e. the air flow rate required for the operation of the sand and grit removal unit), according to the equation (1):

Min air flow rate $=$

Total confined volume*Volume changes + + Inlet air flow rate

The results of the calculations connected with confined volumes and the required air flow rate are reported in the Table 3:

The number and location of the biofilters to be installed at the NWWTP have been designed to minimize the distance from the confined sections, with subsequent minimization of the air pumping head losses, and maximize the operation flexibility. On the basis of the above-mentioned considerations, the installed odor treatment capacity is presented in the Table 4 :

The description and design of the adopted odor treatment units is included in Table 5 (WEF 2004, and Metcalf and Eddy 2003):

Typical elimination capacity is in the range of $20-130 \mathrm{~g} / \mathrm{m}^{3} \mathrm{~h}$ for $\mathrm{H}_{2} \mathrm{~S}$ and other odorants. Considering that the maximum $\mathrm{H}_{2} \mathrm{~S}$ concentration of $100 \mathrm{ppm}$ corresponds to about $136 \mathrm{mg} / \mathrm{m}^{3}$ and considering the removal efficiency of at least $98 \%$, the minimum required elimination capacity can be estimated as follows:

- Required $\mathrm{H}_{2} \mathrm{~S}$ elimination capacity (Biofilter Dimensions- $1(8.9 \times 2.27 \times 2.13) \mathrm{m})=$ $2000 * 136 * 98 / 24 * 1000 * 100=11.3 \mathrm{~g} / \mathrm{m}^{3} \mathrm{~h}$

- Required $\mathrm{H}_{2} \mathrm{~S}$ elimination capacity (Biofilter Dimensions-2 $(10.6 \times 2.27 \times 2.13) \mathrm{m})=$ $5000 \times 136 \times 98 / 60 \times 1000 \times 100=11.1 \mathrm{~g} / \mathrm{m}^{3} \mathrm{~h}$

As results from the above-mentioned calculation, the required elimination capacity for

Table 3. Results of the calculations connected with confined volumes and the required air flow rate

\begin{tabular}{|l|c|c|c|}
\hline \multicolumn{1}{|c|}{ Section } & $\begin{array}{c}\text { Total confined } \\
\text { volume } \\
\left(\mathrm{m}^{3}\right)\end{array}$ & $\begin{array}{c}\text { Design } \\
\text { Volume } \\
\text { changes }\end{array}$ & $\begin{array}{c}\text { Minimum } \\
\text { required air flow rate }\left(\mathrm{Nm}{ }^{3} / \mathrm{h}\right)\end{array}$ \\
\hline Inlet screw pumping station & 400 & $>5$ & 2000 \\
\hline Screening station & 400 & 12 & 4800 \\
\hline Aerated grit - oil-grease removal tank & 800 & 12 & 9600 \\
\hline Parshall flume & 400 & 12 & 4800 \\
\hline
\end{tabular}

Table 4. Biofilter odor treatment capacity

\begin{tabular}{|l|c|c|c|}
\hline \multicolumn{1}{|c|}{ Section } & $\begin{array}{c}\text { Total required } \\
\text { air flow rate } \\
\left(\mathrm{Nm}^{3} / \mathrm{h}\right)\end{array}$ & $\begin{array}{c}\text { Installed } \\
\text { capacity } \\
\left(\mathrm{Nm}^{3} / \mathrm{h}\right)\end{array}$ & $\begin{array}{c}\text { Actual volume } \\
\text { Exchange per hour } \\
\text { biofilters }\end{array}$ \\
\hline Inlet screw pumping station & 2000 & 2000 & 5 \\
\hline Screening station & 4800 & 5000 & 12.5 \\
\hline $\begin{array}{l}\text { Aerated grit - oil-grease removal tank and } \\
\text { Parshall flume }\end{array}$ & 14400 & 15000 & 12.5 \\
\hline
\end{tabular}

Table 5. Biofilter odor treatment capacity

\begin{tabular}{|c|c|c|c|c|}
\hline Parameter & Unit & Suggested range & $\begin{array}{c}\text { Biofilter } \\
\text { Dimensions-1 } \\
(8.9 \times 2.27 \times 2.13) \mathrm{m}\end{array}$ & $\begin{array}{c}\text { Biofilter } \\
\text { Dimensions-2 } \\
(10.6 \times 2.27 \times 2.13) \mathrm{m}\end{array}$ \\
\hline Filtering bed height & $\mathrm{m}$ & $1-1.8$ & 1.4 & 1.4 \\
\hline Average bed porosity & $\%$ & $35-50$ & 40 & 40 \\
\hline Filtering bed surface & $m^{2}$ & - & 17.4 & 42 \\
\hline Filtering bed volume & $\mathrm{m}^{3}$ & - & 24 & 60 \\
\hline Air flow rate & $\mathrm{Nm}^{3} / \mathrm{h}$ & - & 2000 & 5000 \\
\hline Surface loading rate & $\mathrm{m}^{3} / \mathrm{m}^{2} \mathrm{~h}$ & $10-500$ & 115 & 128.5 \\
\hline Volume loading rate & $\mathrm{m}^{3} / \mathrm{m}^{3} \mathrm{~h}$ & $10-100$ & 83 & 90 \\
\hline Empty bed residence time & s & $30-60$ & 42 & 39.2 \\
\hline Design $\mathrm{H}_{2} \mathrm{~S}$ inlet oncentration & ppm & - & 50 & $50-100$ \\
\hline
\end{tabular}




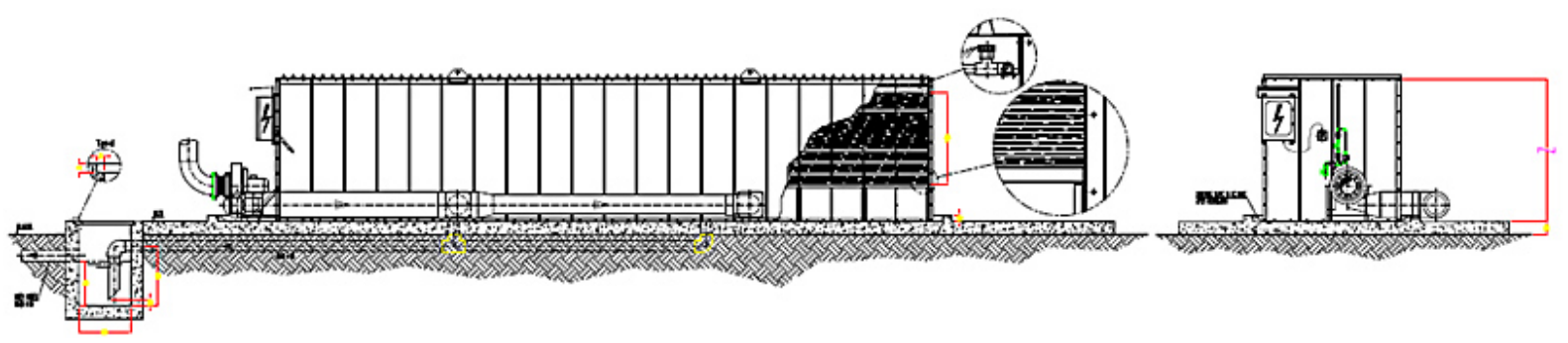

Figure 5. Front view of biofilter

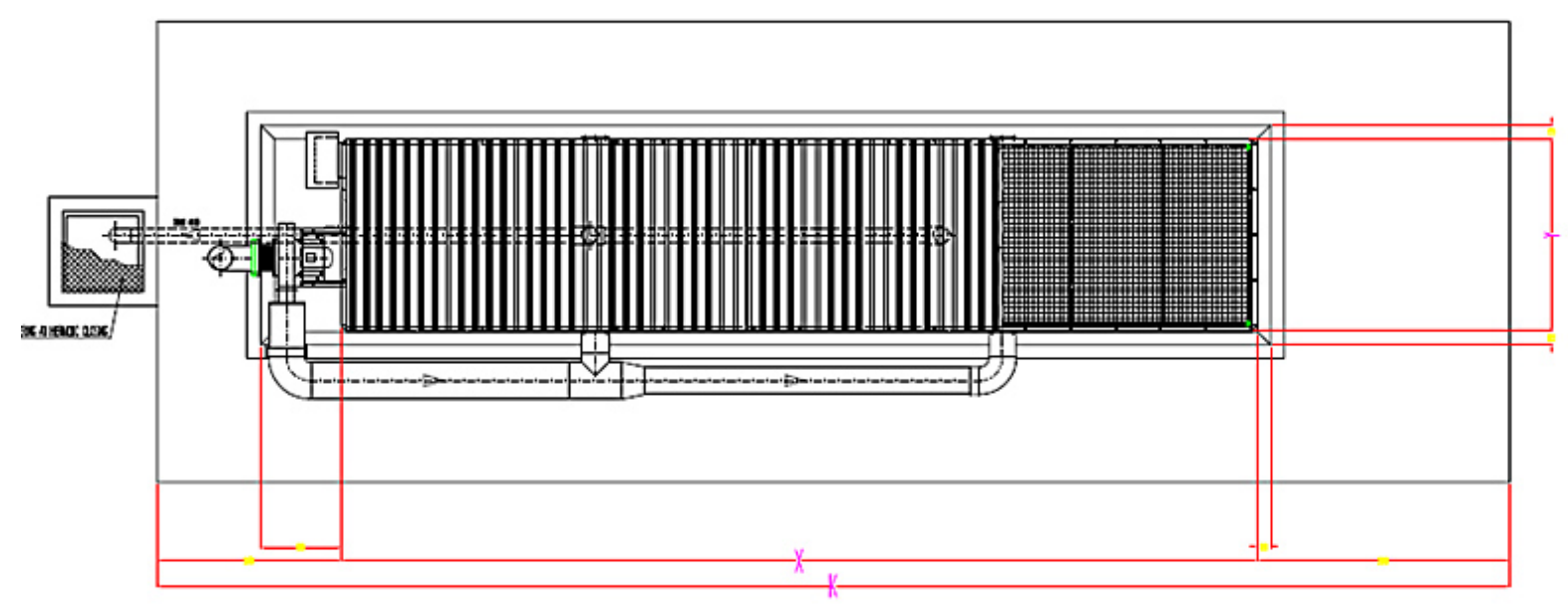

Figure 6. Plan view of biofilter

$\mathrm{H}_{2} \mathrm{~S}$ is far below the typical elimination capacity reported for this type of odor treatment units $\left(20-130 \mathrm{~g} / \mathrm{m}^{3} \mathrm{~h}\right)$; therefore the treatment efficiency will be reached only within the initial part of the filtering bed (Figures 5 and 6).

\section{CONCLUSIONS}

The unwanted and harmful emissions and odors from wastewater treatment plants such as hydrogen sulfide gas and ammonia gas, which cause damage to the population living near these stations, result in the establishment of closed, zero-emission plants. The biofilter filter is designed to remove odors from the wastewater treatment plant in Al-Nasiriyah city, according to the Iraqi environmental regulations. As results from the calculation, the required elimination capacity for $\mathrm{H}_{2} \mathrm{~S}$ is far below the typical elimination capacity reported for this type of odor treatment units (20-130 $\mathrm{g} / \mathrm{m}^{3} \mathrm{~h}$ ); therefore the treatment efficiency will be reached only within the initial part of the filtering bed.

\section{REFERENCES}

1. Ben Jaber, M., Couvert, A., Amrane, A., Rouxel, F., Le Cloirec, P., Dumont, E. 2016. Biofiltration of high concentration of $\mathrm{H} 2 \mathrm{~S}$ in waste air under extreme acidic conditions. New Biotechnology 33, 136-143. doi:10.1016/j.nbt.2015.09.008,

2. Burgess J.E., Parsons S.A., Stuetz R.M., 2001. Developments in odour control and waste gas treatment biotechnology: a review. Biotechnology Advances $19,35-63$.

3. Estrada J.M., Bart Kraakman N.J.R., Muñoz R., and Lebrero R., 2011. A Comparative Analysis of Odour Treatment Technologies in Wastewater Treatment Plants. Environ. Sci. Technol., 2011, 45 (3), pp 1100-1106.

4. Fletcher, L.A., Jones, N., Warren, L., Stentiford, E.I. 2014. Understanding biofilter performance and determining emission concentrations under operational conditions, Final Report - Project Number ER36.

5. Gabriel D. and Deshusses M.A., 2004. Technical and economic analysis of the conversion of a fullscale scrubber to a biotrickling filter for odor control. Water Science and Technology 50, 4, 309-318.

6. Metcalf and Eddy 2003. Wastewater Engineering: Treatment and Reuse. Fourth Edition, McGrawHill, New York. 
7. Pedro Cisterna, 2017. Biological Treatment by Active Sludge with High Biomass Concentration at Laboratory Scale for Mixed Inflow of Sunflower Oil and Saccharose. Environments 2017, 4, 69; doi:10.3390/environments4040069

8. WEF Manual of Practice no. 25, 2004., Control of Odors and Emissions from Wastewater Treatment
Plants, Water Environment Federation. 601 Wythe Street - Alexandria, VA 22314-1994 (USA).

9. WERF 2003. Identifying and Controlling Odor in the Municipal Wastewater Environment. Phase 1: Literature Search and Review. Water Environment Federation, 601 Wythe Street - Alexandria, VA 22314-1994 (USA). 